\title{
Flow Experience and Consumer Willingness to Pay in Online Mass Customization Processes
}

Nur Özer Canarslan, Anadolu University, Turkey

Gülfidan Bariş, Anadolu University, Turkey

\begin{abstract}
This research aims to identify the effects of perceived product value and flow experience during product design on willingness to pay (WTP) and purchase probability in online mass customization. The participants were asked to design shoes to their taste in a custom shoe website. After the design experience, the participants were asked to complete the questionnaire. The analyses suggest that flow experience has a direct effect on consumers' WTP and an indirect effect on purchase probability through the mediating role of perceived value of mass customized products. Furthermore, perceived value of a mass customized product has a significant effect on purchase probability and no effect on WTP found in the analyses.
\end{abstract}

\section{KEYWORDS}

Flow Experience, Mass Customization, Online Shopping Experience, Willingness to Pay

\section{INTRODUCTION AND BACKGROUND}

This study's point of departure is that although mass customization is an extremely attractive and popular concept, it has so many obstacles. The co-design process in mass customization has some complex, risky, and uncertain features that may take customers away from participating in customization (Piller et al. 2005:0). For instance, customers may be confused due to the many options offered in the design process or may perceive a risk of being misled by the online presence of the product they want to acquire. This problem may cause customers to give up buying the items that they co-designed or to reject paying more for the products.

When it comes to business, the researchers indicate that customization allows (and forces) businesses to charge higher prices for their co-designed products and services (Dewan et al. 2003; Cavusoğlu et al. 2007; Jiang et al. 2015) due to two reasons. Firstly, customers are frequently ready to pay a premium that reflects the added value of satisfaction that emerges from customization. Secondly, the raised cost of integrating technology with the customization process requires higher price charges or higher unit costs (Cavusoglu et al. 2007). Therefore, proper management of customization processes by the businesses that desire to apply mass customization as a strategic marketing tool is of great importance. Whereas these reasons are not sufficient, there is another aspect that needs to be focused on by the customization-oriented business under heavy competitive market pressures, i.e., 
online marketing dynamics. It is relatively fast and easy to compare prices in online markets, which supports online customers that are after bargain prices. For instance, the main reason why Turkish consumers prefer online shopping is that they want to access more reasonably priced products (PWC Retail Survey, 2016; Webloyalty Consumer Research, 2016). Similar findings with European sampling were offered by Aichner and Coletti (2013) and found that for $65 \%$ of buyers, the price was the primary source of consumers' attraction. However, as mentioned before, prices for mass customized offers are somewhat higher than standard products, which may reduce consumers' intention to buy mass-customized products and their intention to pay more for them.

In sum, online customization is an attractive strategic tool that offers benefits and obstacles to both businesses and customers. When overcoming the barriers, handling the customization process is the first point to focus on. In their work, Jiang et al. (2015) emphasized that as customization activities become more enjoyable, consumers are likely to engage in them more often. They also suggested the concept of "process value" and related it to Csikszentmihalyi's Flow Theory (1975). Nevertheless, their measure of process value was limited to covering "flow experience" fully. However, Novak et al. (2000) have reported that flow experience is an essential variable in understanding online consumer behaviors in the online environment. Franke and Piller (2003;12), whose works are frequently referenced in mass customization studies, identified a research gap and emphasized that flow experience should be examined as a variable in mass customization studies.

Merle et al. (2010) defined the mass customization experience value as "the interaction between the individual and the product design using a specific method of preference revelation." Csikszentmihalyi (1977, p.36) defined the flow as "the holistic sensation present when acting with total involvement; it is what people feel when they enjoy what they are doing." The term resonates with Merle et al.'s (2010) concept of the hedonic value of mass customization experience.

Considering the research gap pointed and the resonations of the terms offered both in mass customization literature and flow theory, the present paper suggests that if mass customization experience is enriched with an ecstatic state of deep concentration (Csikszentmihalyi describes this ecstasy state as flow) while conducting mass customization, it will increase mass-customized product value. Consequently, customers' probability of buying and WTP more for the designed product in an ecstatic state will be positively affected.

As mentioned before, while overcoming online mass customization obstacles, handling pricing is the second point to focus on. It is challenging to sell customized products, which are somewhat higher to the consumers for whom low prices are known as the most significant source of motivation in preferring online shopping. Ferguson et al. (2014) have stated that economic and cognitive limits are essential factors to consider; if these limits are exceeded, a well-customized product will not be purchased.

Offering consumers a process of designing their products may be perceived as a complex, uncertain, and risky process. Besides, there are online shopping and price dynamics to be considered. Also, it is unknown whether the complicated process of mass customization creates a "flow experience" for the customers. Even if it creates a flow experience, this experience will also affect the product's perceived value. This observation makes up the main problem of this study.

Based on the obstacles mentioned above, the objective of this study is; to empirically identify the direct and indirect effects (through the mass-customized product value) of flow experience on purchase probability and WTP.

\section{THEORETICAL BACKGROUND}

\section{Mass Customization and Mass Customized Product Value}

Stan Davis (1987) used the term "mass customization" for the first time in his work Future Perfect. He defined mass customization as "a process that provides a one-of-a-kind product manufactured 
on a large-scale basis". Following this perspective, Kaplan and Haenlein (2006, p. 177) defined mass customization as "a strategy that creates value by company-customer interaction at the design stage of the operations level to create customized products". Piller (2004, p.314) asserted that there was no common understanding of the concept of mass customization in the literature; therefore, various definitions were proposed. Piller (2004) also emphasized that mass customization cannot be an academic discipline or a business strategy adopted by managers unless a standard definition and understanding is decided. According to Piller, the definition of mass customization should include four elements which are; designing the product together with the customer, meeting the needs of each customer, fixed solution space, fair price, and cost level. Therefore, these four elements are essential in distinguishing mass customization from other concepts of customization.

As Aichner and Coletti (2013) stress, mass customization is necessary to improve a user's personal benefit and demonstrate personal status and strength. Merle et al. (2009) identified two different mass customization value categories as; product and experience value. Similarly, Broekhuizen and Alsem (2002) identified two different kinds of mass customization benefits; instrumental and hedonic benefits. Schreier (2006) identified four different categories of mass customization benefits; perceived uniqueness, functional benefits, pride of authorship and process benefit of self-design (i.e., hedonic, experiential benefit).

Anderson et al. (1992, p.5) define value as "the perceived worth in monetary units of the set of economic, technical, service and social benefits received by a customer in exchange for the price paid for a product, taking into consideration the available suppliers' offerings and prices". In the process of mass customization, the value evaluations of customers who design their very own products via producers' production bases may get a little complicated. When the buyer is involved in the production process, they spend more time and competencies. Simultaneously, Ferguson et al. (2014) assert that customers prefer customized products by the desire to possess their self-designed object without paying the high price of craft manufacturing. However, there is a price premium of the customized product in mass customization compared to the standard one (Piller et al. 2004). At this point, by combining industrial and consumer points of view, there must be an equilibrium between the value evaluations of consumers and the value offers of producers. The equilibrium lies under the assumption that consumers who are willing to buy mass customized products offered by the firms that provide customized products to the masses have an additional WTP more for their self-finished goods. Mass customization "implies that the same large number of customers can be reached as in mass markets of the industrial economy, and simultaneously they can be treated individually as in the customized markets of pre-industrial economies" (Davis, 1987, p.169).

\section{Flow Experience in CMEs and Mass Customization}

Mihalyi Csikszentmihalyi (1975), who suggested the flow theory to the psychology literature, defined flow as "a peculiar dynamic state, a holistic sensation, and a source of happiness that people feel when they act with total involvement" (p. 36). Thus, he evolved his terminology and updated the flow definition as "fully immersion, focus, and mental attachment to an activity (Csikszentmihalyi, 1990)". Later, he described the flow state as "a person's experiences at the highest levels of wellbeing" (Csikszentmihalyi, 2014).

In her paper, Reid (2004) claimed a positive relationship between flow and creativity; nevertheless, her paper relies on case study reports and randomized trials. She also suggests a need for larger trials and more data. Csikszentmihalyi (2014) notes;

"in creativity or optimal experience, I have found that it is always a struggle, and the struggle has to do with essentially opening yourself up and yet delving deeply into yourself... So I see flow as a very important dynamic in the evolution of complexity. It gives you the incentive, the motivation, the reward for going beyond what you have" (p.274). 
Csikszentmihalyi's way of explaining flow and creativity is echoing "mass customization" from consumers' perspectives. Both flow and mass customization theories denote rebelling the standard offers, asking for more, and feeling psychic energy from the creation process (Schreier 2006; Trentin et al. 2014). Besides, the flow concept was also advised as a possible metric of the online consumer experience (Koufaris, 2002, p.207). In their study, Smith and Sivakumar (2004) explored the relationships between online buying behaviors (browsing, buying, and repeat purchasing) and flow experience. Their findings indicate that experienced flow during online shopping can increase the willingness to buy and shop online. Then again, in his critical literature review, Obada (2013) summarized reported relationships between flow and behavioral intentions such as online purchase intentions, revisit intentions or intention to use the Web-based on the works of Agarwal and Karahanna (2000), Luna et al. (2002), Luna et al. (2003), Richard and Chandra (2005), Sanchez-Franco (2006), Bridges and Florsheim (2008).

Flow is a state of rising (ecstasy) that does not emerge when the individual feels very relaxed and takes a rest; on the contrary; it occurs when the individual feels nervous/stressed, has difficulty, and feels good despite all his/her stress and uneasiness (Csikszentmihalyi, 1990). In mass customization, the design process also involves some difficulties for the individual due to its complex, uncertain, and risky structure, as we stated previously. It also requires a certain degree of creativity. However, despite the difficulties, the individual also has the potential to focus on capture the image that he/she has formed the mind while designing the product, be very curious about the product to be obtained as a result of the design process, get the pleasure of creating his/her product, feel that he/she holds the control of the product that will appear in direct proportion to the diversity of the design tools provided by the site in his/her hands.

Besides, the flow may also be a solution for price concerns; in their research, Congwen et al. (2010) exemplified the Taobao website and stated that the site's motto "seek what you like" has become Taobao users' driving force; the joy shoppers found what they like accidentally, its value is much higher than the discount prices. Hinting that if a customer finds pleasure and experiences an ecstatic state of creating and designing his/her product via mass customization, he may buy the product he/she designed at a higher price.

\section{Purchase Probability}

One of the most frequently used methods of estimating target consumers' future buying behavior is to use purchase intention measures. Juster et al. (1966) reported that the numerical measurements would give more accurate results than the intention measurements made through verbal expressions (high probability vs. small probability). They proposed a 10 point numerical purchase probability scale. Clawson (1971) stated that the most commonly used purchase intention scales used until the mid-1960s use 5 point scales. The scales offer statements such as "yes, definitely will buy", "yes, probably will", "might, perhaps, it depends", "no", "don't know". After saying "no", some of the respondents change their decisions and buy the product, which leads to numerous errors in the prediction. They stated that this error was mostly due to the verbally expressed scale's inadequate calibration (partitioning).

As a solution, Clawson then in 1971 proposed a scale between $0 \%$ and $100 \%$ where participants were asked about their possibility of purchase. Dissatisfaction with the accuracy of purchasing behavior estimates based on demographic and socioeconomic variables has made the researchers investigate consumer purchasing intentions and attitudes as an alternative measurement (Juster 1966; Heald 1970; Gabor \& Granger 1972). Wright and Macrae (2007) argued that the likelihood of purchasing is also a form of determining the intention of purchasing, but the responses to the two measurements will differ (p.18). Based on these observations, in this study, the probability of purchase is measured with a statement asking the respondents' likelihood of buying their own-designed sneakers in the next 12 months. The participants were asked to mark between $0 \%$ and $100 \%$ indicating the probability of purchase. 


\section{Willingness to Pay (WTP)}

Wertenbroich and Skiera (2002) conceptualized the term WTP as "the maximum price a buyer is willing to pay for a given quantity of a good". Many recent empirical studies revealed that consumers want to pay more for self-designed products. For example, in their paper in which they explored users' WTP for their self-designed watches Franke and Piller (2003) found out that the WTP for a customized watch is higher than the same quality standard WTP. On average, they found an increase of $100 \%$ WTP for self-designed watches. Similarly, Schreier (2006) found an increase of $207 \%$ in the WTP for self-designed mobile phone covers, an increase of $113 \%$ in the WTP for self-designed T-shirts, and an increase of 106\% in the WTP for self-designed scarfs. Yu and Yang (2020) found an increase of $41.05 \%$ in the WTP for men's ready to wear dress shirt. Kamali and Locker (2002) also reached similar results indicating that customers are ready to pay more to the self-designed products than the standards.

Emphasizing the importance of experience in a design process, Merle et al. (2009) proposed an integrated framework that combines mass customization value components with the WTP for mass customized products. In their model, they divided mass customization value components into two: product value and experience value. They concluded that while the value of the mass customization experience (i.e., experience value) had no direct effect on the WTP, on the other hand, indirectly, the value of the customized product (product value) increases the WTP.

In this paper, the participants were asked their maximum amount of money (in Turkish liras) they would like to pay for a pair of sneakers that are not designed by themselves (i.e., standards) and their maximum amount of money (in Turkish liras) they would like to pay for a pair of sneakers designed by themselves, and their WTP $(\Delta \mathrm{WTP})$ is calculated.

\section{HYPOTHESES DEVELOPMENT}

When the literature on mass customization is viewed, the empirical findings suggest that consumers tend to buy more customized products than standards (Franke et al., 2009; Kamali and Locker, 2002; Wu et al., 2012; Liao et al., 2013). Also, it is found that buying intention is directly related to the degree of customization (Kamali and Locker, 2002), and the perceived value of the customized product increases buying intention directly (Wu et al., 2012) and indirectly (Liao et al., 2013). When these studies are taken into consideration, there is an insight that the customized product's perceived value will influence the purchase intention. Hence our first research hypothesis is:

\section{$\mathrm{H}_{1}$ : Mass customized product value positively influences purchase probability}

The perceived value of a mass-customized product, in the literature, was constructed based on the works of Merle et al. (2009) and Merle et al. (2010), and it is considered as a four-dimensional structure; consisting of utilitarian value, uniqueness value, self-expression value, and creative achievement value. One dimension of this four-dimensional structure, creative achievement value, in a way, may relate to the Flow Experience. Thus, in addition to the assumption of the customization of a product's effect on customers' purchase intentions discussed above, the impact of the flow experience during the design of the product on the purchase intention should also be examined. The most important contribution of the Flow Theory to marketing has been the determination of the effect of flow experience on attitudes, intentions, and behaviors (Hoffman and Novak, 2009, p.29), and in various researches, flow experience has been directly (Luna et al., 2003; Pu et al., 2009a; Pu et al., 2009b; Liu et al., 2016) and indirectly (Pu et al., 2015) related to the intention of purchasing. Ozkara et al. (2017) conclude that three flow subdimensions positively influence online purchase intention; online enjoyment, perceived control, and merging. Besides, Korzaan (2003) found that flow experience increased positive attitude towards online shopping. Bridges and Florsheim (2008, p.309) 
concluded that online consumers who experience flow buy more and return to the site to repeat the experience. Accordingly, our second hypothesis is:

\section{$\mathrm{H}_{2}$ : Flow experience positively influences purchase probability}

As regards the previous research that explores the effect of the perceived value of the customized product and flow experience during customization on purchase intention; the first and second hypotheses of the study are constructed as follows:

Figure 1. Research model

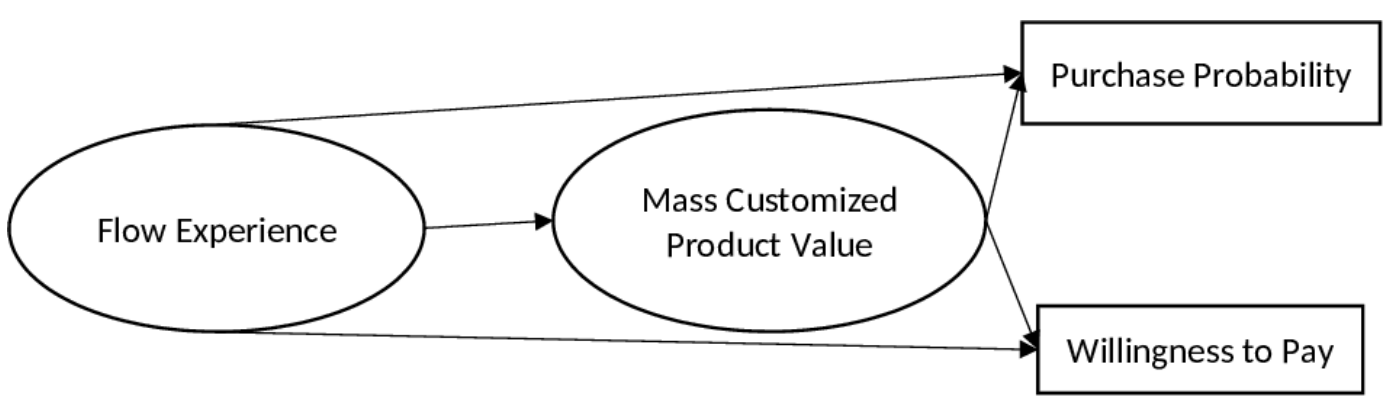

WTP, also referred to as the increase in economic value for mass customized product (Franke and Schreier, 2008), has been addressed in many mass customization studies (Kamali and Locker, 2002; Franke and Piller, 2004; Bardakçı and Whitelock, 2003; Franke and Schreier, 2006; Schreier, 2006; Schoder et al., 2006; Franke et al., 2009; Franke et al., 2010a; Franke et al., 2010b; Yu and Yang, 2020) and customer participation study (Wei et al., 2018). Researchers have suggested that consumers are ready to pay higher amounts for mass customized products because they can get more suitable products for their needs via mass customization (Pine, 1993, p. 46; Peppers and Rogers, 1997, p. 178; Piller, 2002, p.11). Here are some more empirical studies that prove these arguments (Piller, 2002; Franke and Piller, 2004; Franke and Schreier, 2006; Schreier, 2006; Franke et al., 2009; Chen et al. 2020). In sum, all these studies predicted that mass customization leads to an increase in the WTP.

Furthermore, if there is a positive change in consumer's WTP for a mass customized product, it is necessary to determine the factors to which this change is attributed. According to Franke and Schreier (2010), the explanation of the increase in WTP for customized products is the perceived entertainment and process effort factors that originate from the process, along with the product preference fit factor.

Merle et al. (2009) examined the effects of product value and experience value on WTP for mass customized products and concluded that experience value increased the WTP via perceived product value. When these research findings are considered, it is inferred that consumers' WTP for customized products is related to their ability to reach a more suitable product to their preferences and experiences in the design process. Within the scope of these assumptions, the third and fourth hypotheses of the study were inferred as follows:

\section{$\mathrm{H}_{3}$ : Mass customized product value positively influences WTP $\mathrm{H}_{4}$ : Flow experience positively influences WTP}


Franke and Piller (2003) suggested that the customized product and process notions should be considered independent variables in mass customization research. The empirical investigations of the relationship among them need to be explored. Merle et al. (2009), considering this suggestion, examined the effect of mass customization experience value on the value of the mass-customized product and concluded that mass customization experience value directly affected mass-customized product value. Considering the studies mentioned above and considering that mass-customized product is a direct output of the co-design process, there is a foresight that the co-designing experience will also affect the product value. The assumption that mass customization is not independent of product value and experience value predicts that mass-customized product value can act as a mediator in the relationship between flow experience and WTP and flow experience and purchase probability. Within the scope of these assumptions, the fifth, sixth, and seventh hypotheses of the study were inferred as follows:

\section{$\mathrm{H}_{5}$ : Flow experience positively influences mass-customized product value $\mathrm{H}_{6}$ : Mass customized product value mediates the effect of flow experience on WTP $\mathrm{H}_{7}$ : Mass customized product value mediates the effect of flow experience on purchase probability}

\section{METHODOLOGY}

\section{Sample}

This study has a target population of consumers who can make their own purchase decisions living in Turkey. Because of the unavailability of the sampling frame, a non-probability judgmental sampling technique was used. Three hundred thirty completed questionnaires were received at the end of the two weeks.

\section{Procedure}

Flow represents a state, a temporary subjective experience of the human-computer interaction, that can be captured more reliably when measured immediately during or after the interaction (Webster et al., 1993, p.420). Therefore in our research, to implement the survey immediately after the design process (i.e., human-computer interaction), the potential participants were invited to surf into a Web Site that includes; 1) an informative text about the research, 2) an introductory teaser video (https:// youtu.be/y_kfHHVxKKM), 3) the mass customization Web Site link (www.NIKEiD.com.tr) that they are asked to go through to design their sneakers and 4) the survey link. Thus, all the research processes were conducted in one place. At first, a teaser video was uploaded to a video-sharing site and shared by researchers and survey participants on social media. A pretest of the research instrument was conducted using a small sample of undergraduates to ensure that the format, design, and wording of the questions were clear and easy to be understood.

This study used an existing online mass customization website, "NIKEiD". NIKEiD has one of the most advanced mass customization programs in Turkey that uses a configuration toolkit in a B2C consumer setting at the time of the research (2017). As a product category, sports shoes were selected because of their popularity regardless of the age of shoppers and their appropriateness for customization. Moreover in recent mass customization literature sport shoe category is a key research area (Ribeiro et al., 2017; Runfola et al., 2018, Zhou et al., 2019; Kalantari et al.,2021) After visiting the NIKEiD customization program, participants were asked to create their own sports shoes using the program and imagining that they would have made a purchase. They could select styles, fabrics, colors, and patterns and add text or logo when customizing their shoes. Finally, they completed the questionnaire.

Before testing the hypotheses, descriptive statistics were computed to generate the means, standard deviations, and correlations for the study variables. Since research constructs were previously 
identified, confirmatory factor analysis (CFA) was utilized to confirm how well the measured variable represents the constructs (Hair et al., 2010). Structural equation modeling (SEM) was conducted to explore the relationships among constructs because it allowed us to evaluate the relationships among the latent variables at the same time and guarantee statistical efficiency. Baron and Kenny's (1986) four-step approach was used to test mediation. All these steps were performed within the estimated SEM model, and calculations were performed with SPSS 21.0 and AMOS 22.0. Discriminant validity and internal consistency were conducted through MS Excel.

\section{Measures}

The current study relies on the measurements used in the existing literature. Since the scales were initially developed in English, a standard translation and back-translation procedure was conducted.

Mass customized product value was measured by nine items covering three factors: uniqueness value, utilitarian value, and self-expressive value (Merle et al., 2010). Items are rated on a 5-point scale ranging from 1 (totally disagree) to 5 (totally agree).

Flow experience was measured with twelve items covering four factors; control, concentration, curiosity, and intrinsic interest (Webster et al., 1993). Items are rated on a 5-point scale ranging from 1 (totally disagree) to 5 (totally agree).

Purchase probability was measured with one item "What is the probability that you will buy mass-customized sports shoes in the next 12 months? Participants rated from 0 to 100 percent. A five-point verbal purchase intention scale is also used in the study (1: definitely will not buy, 2: probably will not buy, 3: may or may not buy, 4: probably will buy, 5: definitely will buy) to test the reliability and validity of purchase probability measure.

The contingent valuation method was used to measure the WTP for each participant. In the contingent valuation method (CVM), the respondents are directly asked how much they are willing to pay for a product or service (Mitchell and Carson 1989). Precisely, WTP is a ratio-scaled measure of the buyer's subjective value to a product (Wertenbroch and Skiera 2002, p. 228). The difference in $\Delta$ WTP between a mass customized product and the most preferred (chosen) standard product yields the value increment of customization (Harzer, 2013).

Equation 1. Formula for calculating willingness to pay change

$\Delta W T P=\frac{\text { WTPMassCustomizedProduct-WTPStandartProduct }}{\text { WTPStandartProduct }}$

\section{DATA ANALYSIS AND RESULTS}

\section{Demographic Profiles}

Table 1 shows all the demographic variables for this study. The majority of the respondents are female and from the age group of 25-34. It is also showed that the respondents with a bachelor's degree or higher make up a significant percentage of the sample. Besides, quite a high number of participants have a personal monthly income below 4500£. Lastly, a considerable number of them are frequent online shoppers. 
Table 1. Demographic characteristics of participants

\begin{tabular}{|c|c|c|c|}
\hline & & Frequency & Percentage \\
\hline \multirow{2}{*}{ Gender } & Female & 217 & 66 \\
\hline & Male & 113 & 34 \\
\hline \multirow{4}{*}{ Education } & Secondary School & 6 & 2 \\
\hline & High School & 55 & 17 \\
\hline & Bachelor Degree & 157 & 48 \\
\hline & $\mathrm{PhD}$ - Master & 112 & 33 \\
\hline \multirow{4}{*}{ Age } & Less than 25 & 70 & 22 \\
\hline & $25-34$ & 188 & 56 \\
\hline & $35-44$ & 46 & 13 \\
\hline & More than 44 & 26 & 8 \\
\hline \multirow{6}{*}{ Personal Monthly Income } & $1500 €$ and lower & 76 & 23 \\
\hline & $1501-3000 €$ & 96 & 30 \\
\hline & $3001-4500 €$ & 94 & 28 \\
\hline & $4501-6000 €$ & 38 & 11 \\
\hline & $6001-7500 €$ & 10 & 3 \\
\hline & $7501 €$ and higher & 16 & 5 \\
\hline \multirow{6}{*}{ Online Shopping Frequency } & None & 17 & 5 \\
\hline & Once every two or three years & 24 & 8 \\
\hline & Once or several times in a year & 104 & 32 \\
\hline & Once or several times in a month & 153 & 46 \\
\hline & Once or several times in a week & 28 & 8 \\
\hline & Once or several times in a day & 3 & 1 \\
\hline
\end{tabular}

\section{Results Of Statistical Analyses}

Structural equation modeling (SEM) was utilized in this study. SEM helps researchers analyze complex associations among variables and build models. Moreover, two mediation analyses were performed to observe mediation between the variables flow experience - perceived mass customization product value - WTP and flow experience - perceived mass customization product value - purchase probability. Baron and Kenny's (1986) four-step approach was used to provide evidence for mediation. All these steps were applied within the estimated SEM model, and calculations were performed using the IBM SPSS AMOS 24 program.

Because the data were self-reported for all of the variables, it is possible that the common method bias could be present The Harman's one-factor test (Podsakoff and Organ, 1986) was conducted to examine whether common method variance existed in the data set. According to Harman's onefactor test, if common method bias is present, a single factor will explain greater than $50 \%$ of the variance in a principle components factor analysis with no rotation. All the items were entered in an exploratory factor analysis using the unrotated solution to a principal components analysis. The analysis finally showed that all items can be categorized into five factors with an eigenvalue greater than one, rather than a single factor The first factor accounted for $36.8 \%$ of the variance; the first 
factor did not account for a majority of the variance. The results indicated that common method bias was not a serious concern for the current study(Podsakoff et al., 2003).

Consistent with the two-step approach advocated by Gerbing and Anderson (1988), this study first developed the measurement model by conducting confirmatory factor analysis (CFA). Then, the structural model examined and tested the research hypotheses. Table 2 lists standardized coefficients, critical values, error variances, AVE, and composite reliability values. In order to see how current variables shared their variance and how they differed from other measures, discriminant and convergent validity were conducted (Fornell and Larcker, 1981). Thus, in addition to plausible composite reliability coefficients $(\geq .70$; Nunnally,1994), the shared variance between factors was examined with the average variance extracted (AVE), which exceeded 0.50 in most measures. Factor loadings for all measurement items are positive and exceed the threshold value of 0.5. All standardized item loadings are significant $(\mathrm{p}<0.01)$ (Hair et al., 1998). AVE's square root exceeded the correlation with each other factors, suggesting that our measurement scales represent ideal discriminant validity (Table 3). Correlation coefficients suggested that all constructs were correlated positively. Table 4 demonstrates the summary of model evaluations. The goodness of fit statistics were acceptable aside from the GFI. However, a cut-off point of 0.9 is not appropriate under all conditions because both parameter number and sample size can influence it (Shevlin \& Miles, 1998:90)

\section{Investigating the Structural Model}

As shown in Table 5, the findings showed that flow experience had a significant positive direct effect on purchase probability, WTP, and mass-customized product value providing support for hypotheses 2, 4, and 5. Perceived mass-customized product value had a significant positive direct effect on purchase probability but had no direct effect on WTP. Hence, the findings supported Hypothesis 1 but failed to support Hypothesis 3.

A summary of model evaluations is made in Table 6 . The goodness of fit statistics was acceptable aside from the GFI. GFI can be low because both sample size and parameter number can influence it (Sharma et al., 2005; Steiger, 2007).

\section{Mediation Analysis}

Two simple mediation analyses were conducted to assess the effect of perceived mass customization product value on the relationship between flow experience and purchase probability and the relationship between flow experience and WTP. In the mediation analysis, the four-step method put forward by Baron and Kenny (1986) and Judd and Kenny (1981) was used to establish partial or complete mediation. According to Baron and Kenny (1986) and Judd and Kenny (1981), a hypothesis of mediation is supported if the following conditions are met:

(1) The causal variable is associated with the dependent variable (see Fig. 2, c'),

(2) the causal variable is related to the potential mediating variable (see Fig. 2, a),

(3) the potential mediating variable is associated with the outcome variable (see Fig. 2, b), and (4) the relationship between the causal variable and the outcome variable is no longer significant when the potential mediator is included in the model (see Fig. 2, c). 
Table 2. Standardized coefficients, critical values, error variances, AVE, and composite reliability values

\begin{tabular}{|c|c|c|c|c|c|c|}
\hline Factors & Items & $\begin{array}{c}\text { Standard } \\
\text { Coefficient }\end{array}$ & $\begin{array}{l}\text { Critical value } \\
\text { (z-value) }\end{array}$ & $\begin{array}{c}\text { Error } \\
\text { Variance }\end{array}$ & Ave & $\begin{array}{l}\text { Composite } \\
\text { Reliability }\end{array}$ \\
\hline \multirow{3}{*}{$\begin{array}{l}\text { Concentration } \\
(\alpha=0.751)\end{array}$} & Concentration 3 & 0,832 & - & - & 0,505 & 0,747 \\
\hline & Concentration 2 & 0,745 & 10.707 & 0.099 & & \\
\hline & Concentration 1 & 0,518 & 8.320 & 0.087 & & \\
\hline \multirow{3}{*}{$\begin{array}{l}\text { Uniqueness } \\
\text { value } \\
(\alpha=0.780)\end{array}$} & Uniqueness value 1 & 0,65 & - & - & 0,558 & 0,79 \\
\hline & Uniqueness value 2 & 0,816 & 11.015 & 0.121 & & \\
\hline & Uniqueness value 3 & 0,765 & 10.707 & 0.099 & & \\
\hline \multirow{3}{*}{$\begin{array}{l}\text { Self } \\
\text { Expressiveness } \\
\text { Value } \\
(\alpha=0.817)\end{array}$} & Self Expressiveness 3 & 0,797 & 15.042 & 0.071 & 0,604 & 0,82 \\
\hline & Self Expressiveness 1 & 0,738 & 13.773 & 0.070 & & \\
\hline & Self Expressiveness 2 & 0,794 & - & -- & & \\
\hline \multirow{3}{*}{$\begin{array}{l}\text { Control } \\
(\alpha=0.755)\end{array}$} & Control 3 & 0,555 & - & - & 0,538 & 0,772 \\
\hline & Control 2 & 0,744 & 9.355 & 0.154 & & \\
\hline & Control 1 & 0,869 & 9.773 & 0.169 & & \\
\hline \multirow{3}{*}{$\begin{array}{l}\text { Utilitarian Value } \\
(\alpha=0.815)\end{array}$} & Utilitarian Value 3 & 0,851 & - & - & 0,598 & 0,816 \\
\hline & Utilitarian Value 2 & 0,751 & 15.136 & 0.058 & & \\
\hline & Utilitarian Value 1 & 0,71 & 14.044 & 0.052 & & \\
\hline \multirow{3}{*}{$\begin{array}{l}\text { Curiosity } \\
(\alpha=0.775)\end{array}$} & Curiosity 1 & 0,628 & 10.091 & 0.082 & 0,564 & 0,795 \\
\hline & Curiosity 3 & 0,726 & - & - & & \\
\hline & Curiosity 2 & 0,8 & 12.154 & 0.092 & & \\
\hline \multirow{3}{*}{$\begin{array}{l}\text { Intristic Interest } \\
(\alpha=0.736)\end{array}$} & Intristic Interest 1 & 0,802 & 10.634 & 0.109 & 0,482 & 0,734 \\
\hline & Intristic Interest 2 & 0,628 & 9.169 & 0.093 & & \\
\hline & Intrinsic Interest 3 & 0,639 & - & - & & \\
\hline \multirow{4}{*}{$\begin{array}{l}\text { Flow } \\
\text { Experience }\end{array}$} & Control & 0,794 & & & 0,606 & 0,858 \\
\hline & Intrinsic Interest & 0,867 & & & & \\
\hline & Concentration & 0,583 & & & & \\
\hline & Curiosity & 0,837 & & & & \\
\hline \multirow{3}{*}{$\begin{array}{l}\text { MC Product } \\
\text { Value }\end{array}$} & Uniqueness value & 0,674 & & & 0,597 & 0,811 \\
\hline & Utilitarian Value & 0,964 & & & & \\
\hline & Self Expressiveness Value & 0,94 & & & & \\
\hline
\end{tabular}


Table 3. The square root of AVE (shown as bold at diagonal) and factor correlation coefficients

\begin{tabular}{|l|l|l|l|l|l|l|l|}
\hline & $\begin{array}{l}\text { Uniqueness } \\
\text { Value }\end{array}$ & $\begin{array}{l}\text { Self } \\
\text { Expressive } \\
\text { Value }\end{array}$ & $\begin{array}{l}\text { Utilitarian } \\
\text { Value }\end{array}$ & Control & Concentration & $\begin{array}{l}\text { Intrinsic } \\
\text { Interest }\end{array}$ & Curiosity \\
\hline $\begin{array}{l}\text { Uniqueness } \\
\text { Value }\end{array}$ & $\mathbf{0 , 7 4 6 *}$ & & & & & \\
\hline $\begin{array}{l}\text { Self Expressive } \\
\text { Value }\end{array}$ & 0,535 & $\mathbf{0 , 7 7 7 *}$ & & & & & \\
\hline $\begin{array}{l}\text { Utilitarian } \\
\text { Value }\end{array}$ & 0,498 & 0,753 & $\mathbf{0 , 7 7 3} *$ & & & & \\
\hline Control & 0,356 & 0,484 & 0,614 & $\mathbf{0 , 7 3 3 *}$ & & & \\
\hline Concentration & 0,226 & 0,302 & 0,346 & 0,334 & $\mathbf{0 , 7 1 0 *}$ & & \\
\hline $\begin{array}{l}\text { Intrinsic } \\
\text { Interest }\end{array}$ & 0,327 & 0,388 & 0,310 & 0,492 & 0,310 & $\mathbf{0 , 6 9 4} *$ & \\
\hline Curiosity & 0,382 & 0,415 & 0,301 & 0,518 & 0,301 & 0,632 & $\mathbf{0 , 7 5 0 *}$ \\
\hline
\end{tabular}

*Diagonal elements (in italics) represent the square roots of the AVE's for individual constructs.

Table 4. CFA model evaluations

\begin{tabular}{|l|l|l|}
\hline & \multicolumn{1}{|c|}{ Criteria } & \multicolumn{1}{c|}{ Model Fit Values } \\
\hline$x^{2} / d f$ & $\begin{array}{l}\leq 3 \text { Excellent } * \\
\leq 5 \text { Acceptable* }\end{array}$ & 2,713 \\
\hline RMSEA & $0 \leq \mathrm{RMSEA} \leq 0,08 * *$ & 0,072 \\
\hline GFI & $0,90 \leq \mathrm{GFI} \leq 1,00 * *$ & 0,874 \\
\hline CFI & $0,90 \leq \mathrm{GFI} \leq 1,00 * *$ & 0,903 \\
\hline$*$ Hair et al. $2010 * *$ Schumacker \& Lomax, 1996 & \\
\hline
\end{tabular}

Table 5. Path coefficients, critical values, and hypotheses results

\begin{tabular}{|l|l|l|l|l|}
\hline \multicolumn{1}{|c|}{ Hypotheses } & \multicolumn{1}{|c|}{ Structural Path } & \multicolumn{1}{c|}{ Path Coefficients } & \multicolumn{1}{c|}{$\begin{array}{c}\text { Critical Value } \\
\text { (Z Statistics) }\end{array}$} & \multicolumn{1}{c|}{ Supported } \\
\hline $\mathbf{H}_{\mathbf{1}}$ & $\mathrm{MCPV} \rightarrow \mathrm{PP}$ &, $303 * * *$ & 3,345 & Yes \\
\hline $\mathbf{H}_{\mathbf{2}}$ & $\mathrm{FE} \rightarrow \mathrm{PP}$ &, $199 * *$ & 2,131 & Yes \\
\hline $\mathbf{H}_{\mathbf{3}}$ & $\mathrm{MCPV} \rightarrow \mathrm{WTP}$ &, 016 & 0,161 & No \\
\hline $\mathbf{H}_{\mathbf{4}}$ & $\mathrm{FE} \rightarrow \mathrm{WTP}$ &, 294 & 2,897 & Yes \\
\hline $\mathbf{H}_{\mathbf{5}}$ & $\mathrm{FE} \rightarrow \mathrm{MCPV}$ & 10,061 & Yes \\
\hline $\begin{array}{l}\text { Notes: } * * * \\
\text { probability; }<0.001 ; * * \mathrm{WTP}=\text { willingness to pay }\end{array}$ &, 719 & \multicolumn{2}{l}{} \\
\hline
\end{tabular}


Table 6. Goodness of fit statistics for the model and critical fit values

\begin{tabular}{|l|l|l|l|l|}
\hline Fit Statistics & Model Fit Values & Acceptable Fit & Good Fit & Excellent Fit \\
\hline $\boldsymbol{x}^{2} / \mathrm{s} \boldsymbol{d}$ & 2,713 & $3-5$ & - & $\leq 3$ \\
\hline RMSEA & 0,072 & $0.08-0.10$ & $0.05-0.08$ & $\leq 0.05$ \\
\hline GFI & $\mathbf{0 , 8 7 4}$ & - & $\geq 0.90$ & $\geq 0.95$ \\
\hline CFI & $\mathbf{0 , 9 0 3}$ & - & $\geq 0.90$ & $\geq 0.95$ \\
\hline
\end{tabular}

If the criteria for all four of these steps are met, then the data are consistent with the hypothesis that the mediating variable fully mediates the relationship, supporting full mediation. On the other hand, if the first three steps are met but in the fourth step when the potential mediator is included in the model, the relationship between the independent variable and the dependent variable gets lower (in Fig. 2., when $\mathrm{c}<\mathrm{c}^{\prime}$ ) then partial mediation is indicated.

Figure 2.

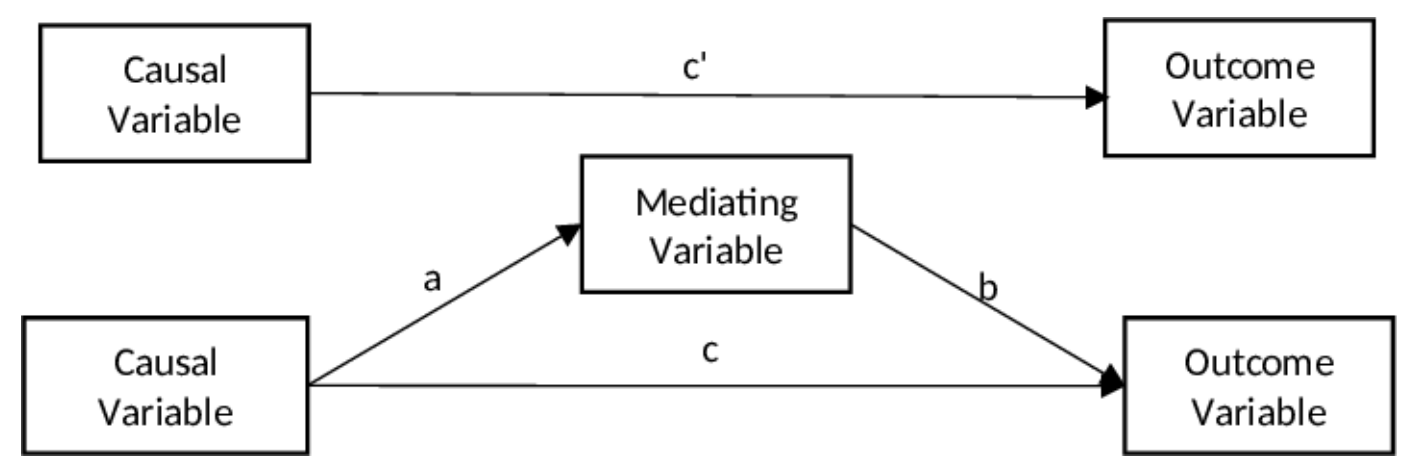

\section{Flow Experience - Willingness to Pay Mediation Analysis}

For the sixth hypothesis, Baron and Kenny's (1986) and Judd and Kenny's (1981) mediation steps were applied within the hypothesized model explained below:

1. In the first step of our mediation analysis, the direct impact of flow experience on WTP was significant and positive, and the path coefficient was $0,289, \mathrm{p}<.01$; Step 1 was approved.

2. In the second step of our mediation analysis, flow experience had a positive and significant impact on perceived mass customization product value, and the path coefficient was $0,718, \mathrm{p}<$ .01. Step 2 was approved.

3. In the third step of our mediation analysis, the effect of perceived mass-customized product value on WTP was not significant, $\mathrm{p}<.01$. Step 3 was not approved.

Because the third step criterion was not met, hypothesis 6 was rejected. 


\section{Flow Experience - Purchase Probability Mediation Analysis}

For the seventh hypothesis, Baron and Kenny's (1986) and Judd and Kenny's (1981) mediation steps were applied within the hypothesized model explained below:

1. In the first step of mediation analysis, the direct impact of flow experience on purchase probability was positive and significant, path coefficient was $0,398, \mathrm{p}<.01$. Step 1 was approved.

2. In the second step of mediation analysis, flow experience had a positive and significant impact on perceived mass customization product value, and the path coefficient was $0,717, \mathrm{p}<.01$. Step 2 was approved.

3. In the third step of mediation analysis, perceived mass-customized product value had a positive and significant impact on purchase probability, and the path coefficient was $0,318, p<.01$. Step 3 was approved.

4. In the fourth step of mediation analysis, when the potential mediator was included in the model, the relationship between the causal variable flow experience and outcome variable purchase probability was no longer significant. The path coefficient was $0,178, \mathrm{p}>.05$. Step 4 was approved.

Baron and Kenny (1986) and Judd and Kenny's (1981) four-step approach revealed a full mediation of perceived mass-customized product value in the relationship between flow experience and purchase probability.

A general evaluation of the mediation analysis results, as shown in Table 7, indicates that the perceived mass-customized product value mediates the relationship between flow experience and purchase probability.

Table 7. Hypotheses results for mediations

\begin{tabular}{|l|l|l|l|l|}
\hline Hypotheses & Causal Variable & $\begin{array}{l}\text { Mediating } \\
\text { Variable }\end{array}$ & Outcome Variable & Supported \\
\hline $\mathrm{H}_{6}$ & FE & MCPV & WTP & No \\
\hline $\mathrm{H}_{7}$ & FE & MCPV & PP & Yes \\
\hline
\end{tabular}

Notes: $\mathrm{FE}=$ flow experience; $\mathrm{MCPV}=$ mass customized product value; $\mathrm{PP}=$ purchase probability; $\mathrm{WTP}=$ willingness to pay

\section{CONCLUSION}

The goal of this research was to empirically identify the direct and indirect effects of flow experience on purchase probability and WTP in online mass customization processes and introduces a model to achieve this aim.

In this study, it was revealed that consumers' flow experience while designing their products on Websites that offer mass customization service to their customers has a direct effect on the WTP and an indirect effect on the purchase probability through the perceived value of the mass-customized product. We can explain this with two scenarios:

Scenario 1: If customers do not experience a flow state during designing their product on the mass customization website while perceiving the customized product by themselves as a valuable product, they may think that the product reflects their uniqueness, originality, and personality. The customer buys products that meet his tastes. Therefore, in this scenario, the probability of purchasing a customized product will be directly and positively affected; however, customers may not be willing to pay more for it. 
Scenario 2: If customers experience a flow state during their product's designing process on the mass customization website, they will evaluate the self-designed products as more valuable. Since the value of the flow state will be reflected in the product designed during the flow state, the possibility of purchasing and the WTP more for the self-designed products will be positively affected.

This study make several theoretical contributions to the field of marketing. The research is the first study in the literature investigating experiences in the online mass customization process in detail within a scope of the flow experience and its corresponding effects. Hoffman and Novak (2009) state that, from a marketing perspective, the most critical outcome of flow theory is its influence on attitudes, subsequent behavioral intentions, and behaviors. In light of this study's results, it was showed that there is a direct positive effect of the flow experience on the WTP, which may contribute to the marketing literature by highlighting the marketing outcomes of the flow experience.

The findings of the study offer some significant advantages to entrepreneurs, brand managers, and marketing managers who are already applying or who aim to implement online mass customization. It can be concluded that it would be difficult for the practitioners to persuade Turkish customers who stated that the most significant motivational source for choosing the online channels was the lower prices related to online mass customization at higher prices compared to the products of mass production. To this end, it is crucial to determine what factors increase the customers' WTP and their degree of influence. The literature says that consumers are willing to pay more for the products they have designed (Franke et al., 2010), or they are willing to pay more for the products they think they have contributed to their design process (Norton et al., 2011, Wei et al., 2018). WTP varies according to the product category and may reach up to $200 \%$ (Schreier, 2006). In the present study, an increase of $25 \%$ WTP for the sneakers designed by the respondents was observed. Although the increase in WTP observed in this study seemed relatively low compared to $200 \%$ increases in different researches. These previous papers explored WTP for mass customized sneakers made earlier reached some similarities to the results of this study, among which a $30 \%$ increase in payment requests was observed (Merle et al., 2008; Merle et al., 2009; Piller, 2002). This result shows the practitioners that the prices they will set for the customized product should consider the type of product they would offer for customization and the standard products' price level.

In other words, the price-sensitive online consumer who designed their sneakers buy these sneakers not because they suit his/her needs better, their originality, nor their ability to reflect individual tastes but for the flow experience he/she had while designing the sneakers (for instance he/she was able to focus, to feel inner interest for it; and feel of personal control over the outcome). $\mathrm{He} / \mathrm{she}$, therefore, wants to pay more.

Simultaneously, the flow experience increased the perceived value of the customized product, thereby increasing the likelihood of purchase. When online marketing executives focus only on the value of mass-customized product such as its' uniqueness, originality, individuality, etc. but not the experience that the customer during the customization process, clearly the customer will perceive the product "valuable" since she or he designed it. Therefore she/he will evaluate the possibility of purchasing the self-designed product high. Nevertheless, when it comes to paying more for the customized product, his/her WTP higher prices will suddenly decrease and leave the shopping basket since he/she did not experience a flow experience. Therefore, online marketing managers who want to sell mass customized products that are slightly more expensive than the standard ones are advised to design their sites, and mass customization toolsets in such a way that consumers will experience flow (i.e., curious, interesting, not distracting, and giving control to the customers) is required.

Under these circumstances, it is of great importance for online marketing executives who aim to implement mass customization to design their Websites and mass customization toolsets to arouse curiosity and attract attention. Also, they should not distract the customer, and they need to offer customers a level of customization so that he/she feels that he/she is in control of the design process. 
As a result, it is showed that the variable of "flow experience", which has not been studied in detail before, is of great importance in the process of mass customization in the design process. The present research findings also revealed that managing "the experience" in the self-design process to create flow will contribute significantly to the advancement of businesses.

\section{Limitations and Future Research}

Although this study provides fascinating insights into how flow experience influences perceived mass-customized product value, WTP, and purchase probability, it has several limitations. First of all, the study used a convenience sample; therefore, interpretation and generalization of the findings should be made carefully. Future research should include a larger sample of consumers to test the results of this study. Secondly, the product category used in the present study was sports shoes. Therefore, respondents' evaluations of mass customization were only based on a single category of product. Other studies should focus on various types of products. Besides, the Nike ID program is an example of "partial customization" (Duray et al. 2000); it would be worth testing the proposed model on other types of customization programs. Although before starting customization, respondents were asked to imagine that they had actually purchased their design, the experiment remains virtual, hence lacks realism. 


\section{REFERENCES}

Aichner, T., \& Coletti, P. (2013). Customers' online shopping preferences in mass customization. Journal of Direct, Data and Digital Marketing Practice, 15(1), 20-35. doi:10.1057/dddmp.2013.34

Agarwal, R., \& Karahanna, E. (2000). Time flies when you're having fun: Cognitive absorption and beliefs about information technology usage. Management Information Systems Quarterly, 24(4), 665-694. doi:10.2307/3250951

Anderson, J. C., Jain, D. C., \& Chintagunta, P. K. (1992). Customer value assessment in business markets: A state-of-practice study. Journal of Business-To-Business Marketing, 1(1), 3-29. doi:10.1300/J033v01n01_02

Bardakçı, A., \& Whitelock, J. (2003). Mass-customization in marketing: The consumer perspective. Journal of Consumer Marketing, 20(5), 463-479. doi:10.1108/07363760310489689

Baron, R. M., \& Kenny, D. A. (1986). The moderator-mediator variable distinction in social psychological research: Conceptual, strategic, and statistical considerations. Journal of Personality and Social Psychology, 51(6), 1173-1182. doi:10.1037/0022-3514.51.6.1173 PMID:3806354

Bridges, E., \& Florsheim, R. (2008). Hedonic and utilitarian shopping goals: The online experience. Journal of Business Research, 61(4), 309-314. doi:10.1016/j.jbusres.2007.06.017

Broekhuizen, T. L. J., \& Alsem, K. J. (2002). Success factors for mass customization: A conceptual model. Journal of Market Focused Management, 5(4), 309-330. doi:10.1023/B:JMFM.0000008072.35988.ef

Cavusoglu, H., Cavusoglu, H., \& Raghunathan, S. (2007). Selecting a customization strategy under competition: Mass customization, targeted mass customization, and product proliferation. IEEE Transactions on Engineering Management, 54(1), 12-28. doi:10.1109/TEM.2006.889064

Congwen, D., Jiabin, Y., \& Shuxian, J. (2010, January). The characteristics of web site and consumer online shopping conduct: an empirical study based on flow experience. In 2010 International Conference on Logistics Systems and Intelligent Management (ICLSIM) (Vol. 3, pp. 1774-1778). doi:10.1109/ICLSIM.2010.5461306

Clawson, C. J. (1971). How useful are 90-day purchase probabilities? Journal of Marketing, 35(4), 43-47. doi:10.1177/002224297103500408

Csikszentmihalyi, M. (1975). Beyond boredom and anxiety. Jossey-Bass.

Csikszentmihalyi, M. (1990). Flow: The psychology of optimal performance. Cambridge University Press.

Csikszentmihalyi, M., \& Larson, R. (2014). Flow and the foundations of positive psychology (Vol. 10). Springer. doi:10.1007/978-94-017-9088-8

Dewan, R., Jing, B., \& Seidmann, A. (2003). Product customization and price competition on the Internet. Management Science, 49(8), 1055-1070. doi:10.1287/mnsc.49.8.1055.16401

Ferguson, S. M., Olewnik, A. T., \& Cormier, P. (2014). A review of mass customization across marketing, engineering, and distribution domains toward development of a process framework. Research in Engineering Design, 25(1), 11-30. doi:10.1007/s00163-013-0162-4

Fornell, C., \& Larcker, D. F. (1981). Structural equation models with unobservable variables and measurement error: Algebra and statistics. JMR, Journal of Marketing Research, 18(3), 382-388. doi:10.1177/002224378101800313

Franke, N., \& Piller, F. T. (2003). Key research issues in user interaction with user toolkits in a mass customisation system. International Journal of Technology Management, 26(5-6), 578-599. doi:10.1504/IJTM.2003.003424

Franke, N., Keinz, P., \& Steger, C. J. (2009). Testing the value of customization: When do customers really prefer products tailored to their preferences? Journal of Marketing, 73(5), 103-121. doi:10.1509/jmkg.73.5.103

Franke, N., \& Schreier, M. (2006). I made this myself! Exploring process utility in mass customization. Enhancing Knowledge Development in Marketing, 14.

Franke, N., \& Schreier, M. (2008). Product uniqueness as a driver of customer utility in mass customization. Marketing Letters, 19(2), 93-107. doi:10.1007/s11002-007-9029-7 
Franke, N., Schreier, M., \& Kaiser, U. (2010a). The “I designed it myself” effect in mass customization. Management Science, 56(1), 125-140. doi:10.1287/mnsc.1090.1077

Franke, N., Keinz, P., \& Steger, C. J. (2010b). Customization: A Goldmine or a Wasteland? GfK Marketing Intelligence Review, 2(2), 26-33. doi:10.2478/gfkmir-2014-0060

Gabor, A., \& Granger, C. W. J. (1972). Ownership and acquisition of consumer durables: Report on the Nottingham consumer durables project. European Journal of Marketing, 6(4), 234-248. doi:10.1108/EUM0000000005145

Gerbing, D. W., \& Anderson, J. C. (1988). An Updated Paradigm for Scale Development Incorporating Unidimensionality and Its Assessment. JMR, Journal of Marketing Research, 25(2), 186-192. doi:10.1177/002224378802500207

Hair, J. F., Anderson, R. E., Babin, B. J., \& Black, W. C. (2010). Multivariate data analysis: A global perspective (Vol. 7). Pearson.

Harzer, S. T. (2013). Value creation through mass customization: An empirical analysis of the requisite strategic capabilities (Doctoral dissertation). Aachen University.

Heald, G. I. (1970). The relationship of intentions to buy consumer durables with levels of purchase. British Journal of Marketing, 4(Summer), 87-97. doi:10.1108/EUM0000000005187

Hoffman, D. L., \& Novak, T. P. (2009). Flow online: Lessons learned and future prospects. Journal of Interactive Marketing, 23(1), 23-34. doi:10.1016/j.intmar.2008.10.003

Jiang, P., Balasubramanian, S. K., \& Lambert, Z. V. (2015). Responses to customized products: The consumers' behavioral intentions. Journal of Services Marketing, 29(4), 314-326. doi:10.1108/JSM-01-2014-0019

Judd, C. M., \& Kenny, D. A. (1981). Estimating the Effects of Social Interventions. Cambridge University Press.

Juster, F. T. (1966). Consumer buying intentions and purchase probability: An experiment in survey design. Journal of the American Statistical Association, 61(315), 658-696. doi:10.1080/01621459.1966.10480897

Kalantari, H. D., Johnson, L. W., \& Perera, C. R. (2021). The effect of gender on willingness to pay for mass customised running shoes. Journal of Global Fashion Marketing, 1-15.

Kamali, N., \& Locker, S. (2002). Mass Customization: Online Consumer Involvement in Product Design. Journal of Computer-Mediated Communication, 7(4), 0. doi:10.1111/j.1083-6101.2002.tb00155.x

Kaplan, A. M., \& Haenlein, M. (2006). Toward a parsimonious definition of traditional and electronic mass customization. Journal of Product Innovation Management, 23(2), 168-182. doi:10.1111/j.15405885.2006.00190.x

Korzaan, M. L. (2003). Going with the Flow: Predicting Online Purchase Intentions. Journal of Computer Information Systems, 43(4), 25-31.

Koufaris, M. (2002). Applying the technology acceptance model and flow theory to online consumer behavior. Information Systems Research, 13(2), 205-223. doi:10.1287/isre.13.2.205.83

Liao, J. F., Chen, H. Q., \& Cai, P. E. (2013). The Influence of Consumers' Need for Uniqueness on Perceived Value and Purchase Intention. In Proceedings of 20th International Conference on Industrial Engineering and Engineering Management (pp. 1135-1144). Springer. doi:10.1007/978-3-642-40072-8_112

Liu, H., Chu, H., Huang, Q., \& Chen, X. (2016). Enhancing the flow experience of consumers in China through interpersonal interaction in social commerce. Computers in Human Behavior, 58, 306-314. doi:10.1016/j. chb.2016.01.012

Luna, D., Peracchio, L. A., \& de Juan, M. D. (2002). Cross-cultural and cognitive aspects of website navigation. Journal of the Academy of Marketing Science, 30(4), 397-410. doi:10.1177/009207002236913

Luna, D., Peracchio, L. A., \& Juan, M. D. (2003). Flow in individual Web sites: Model Estimation and crosscultural validation. Advances in Consumer Research. Association for Consumer Research (U. S.), (30), $280-281$.

Merle, A., Chandon, J. L., \& Roux, E. (2008). Understanding the perceived value of mass customization: The distinction between product value and experiential value of co-design. Recherche et Applications en Marketing, 23(3), 27-50. doi:10.1177/076737010802300301 
Merle, A., Chandon, J. L., \& Roux, E. (2009). Why consumers are willing to pay for mass customized products: Dissociating product and experiential value. In Handbook of Research in Mass Customization and Personalization. World Scientific Publishing.

Merle, A., Chandon, J. L., Roux, E., \& Alizon, F. (2010). Perceived Value of the Mass-Customized Product and Mass Customization Experience for Individual Consumers. Production and Operations Management, 19(5), 503-514. doi:10.1111/j.1937-5956.2010.01131.x

Novak, T. P., Hoffman, D. L., \& Yung, Y.-F. (2000). Measuring the Customer Experience in Online Environments: A Structural Modeling Approach. Marketing Science, 1(19), 22-42. doi:10.1287/mksc.19.1.22.15184

Nunnally, J. C., \& Bernstein, I. H. (1994). The assessment of reliability. Psychometric Theory, 3(1), 248-292.

Obadă, D. R. (2013). Flow theory and online marketing outcomes: A critical literature review. Procedia Economics and Finance, 6, 550-561. doi:10.1016/S2212-5671(13)00173-1

Ozkara, B. Y., Ozmen, M., \& Kim, J. W. (2017). Examining the effect of flow experience on online purchase: A novel approach to the flow theory based on hedonic and utilitarian value. Journal of Retailing and Consumer Services, 37, 119-131. doi:10.1016/j.jretconser.2017.04.001

Peppers, D., \& Rogers, M. (1997). Enterprise one-to-one future. Academic Press.

Piller, F. T. (Ed.). (2002). The Market for Customized Footwear in Europe: Market Demand and Consumer's Preferences. EuroShoe Consortium. www.aib.ws.tum.de/piller

Piller, F. T. (2004). Mass customization: Reflections on the state of the concept. International Journal of Flexible Manufacturing Systems, 16(4), 313-334. doi:10.1007/s10696-005-5170-х

Piller, F. T., Moeslein, K., \& Stotko, C. M. (2004). Does mass customization pay? An economic approach to evaluate customer integration. Production Planning and Control, 15(4), 435-444. doi:10.1080/0953728042000238773

Piller, F., Schubert, P., Koch, M., \& Möslein, K. (2005). Overcoming mass confusion: collaborative customer co-design in online communities. Journal of Computer-Mediated Communication, 10(4).

Pine, B. J. (1993). Mass customization: the new frontier in business competition. Harvard Business Press.

Pu, W., Chen, K. H., Shieh, M. D., \& Fang, H. M. (2009a). The effect of customization service on flow experience and behavior intensions in customer co-design process. In Proceedings of the Ninth International Conference on Electronic Business (ICEB) (pp. 201-208). Academic Press.

Pu, W. P., Chen, K. H., Shieh, M. D., \& Fang, H. M. (2009b). Customer co-design and flow experience of customization product producing process in computer-mediated environments. Proceedings of the International Conference on Electronic Business.

Pu, W. P., Chen, K., \& Shieh, M. D. (2015). The effect of co-design and flow experience on customer satisfaction and purchase intention online. Issues in Business Management and Economics, 3, 59-66.

PricewaterhouseCoopers. (2016). They say they want a revolution. Total Retail Survey-2016. https://www.pwc. $\mathrm{com} / \mathrm{gx} / \mathrm{en} / \mathrm{retail}-\mathrm{consumer} /$ publications/assets/total-retail-global-report.pdf

Reid, D. (2004). A model of playfulness and flow in virtual reality interactions. Presence (Cambridge, Mass.), 13(4), 451-462. doi:10.1162/1054746041944777

Ribeiro, L. S., Duarte, P. A. O., \& Miguel, R. (2017). Online consumer behaviour of mass-customised apparel products: A hierarchy of traits approach. Journal of Fashion Marketing and Management, 21(2), 158-171. doi:10.1108/JFMM-07-2016-0068

Richard, M. O., \& Chandra, R. (2005). A model of consumer web navigational behavior: Conceptual development and application. Journal of Business Research, 58(8), 1019-1029. doi:10.1016/j.jbusres.2004.04.001

Runfola, A., Temperini, V., \& Gregori, G. L. (2018). Problematizing customization and IT in the fashion industry: A case study of an Italian shoemaker AU - Perna, Andrea. Journal of Global Fashion Marketing, 9(1), 73-86. doi:10.1080/20932685.2017.1399081

Sanchez-Franco, M. J. (2006). Exploring the influence of gender on web usage via partial least squares. Behaviour \& Information Technology, 25(1), 19-36. doi:10.1080/01449290500124536 
Schoder, D., Sick, S., Putzke, J., \& Kaplan, A. M. (2006). Mass customization in the newspaper industry: Consumers' attitudes toward individualized media innovations. The International Journal on Media Management, 8(1), 9-18. doi:10.1207/s14241250ijmm0801_3

Schreier, M. (2006). The value increment of mass-customized products: An empirical assessment. Journal of Consumer Behaviour, 5(4), 317-327. doi:10.1002/cb.183

Shevlin, M., \& Miles, J. N. (1998). Effects of sample size, model specification and factor loadings on the GFI in confirmatory factor analysis. Personality and Individual Differences, 25(1), 85-90. doi:10.1016/S01918869(98)00055-5

Smith, D. N., \& Sivakumar, K. (2004). Flow and Internet shopping behavior: A conceptual model and research propositions. Journal of Business Research, 57(10), 1199-1208. doi:10.1016/S0148-2963(02)00330-2

Trentin, A., Perin, E., \& Forza, C. (2014). Increasing the consumer-perceived benefits of a mass-customization experience through sales-configurator capabilities. Computers in Industry, 65(4), 693-705. doi:10.1016/j. compind.2014.02.004

Webster, J., Trevino, L. K., \& Ryan, L. (1993). The dimensionality and correlates of flow in human-computer interactions. Computers in Human Behavior, 9(4), 411-426. doi:10.1016/0747-5632(93)90032-N

Wei, S., Ang, T., \& Jancenelle, V. E. (2018). Willingness to pay more for green products: The interplay of consumer characteristics and customer participation. Journal of Retailing and Consumer Services, 45, $230-238$. doi:10.1016/j.jretconser.2018.08.015

Wertenbroch, K., \& Skiera, B. (2002). Measuring consumers' willingness to pay at the point of purchase. JMR, Journal of Marketing Research, 39(2), 228-241. doi:10.1509/jmkr.39.2.228.19086

Wright, M., \& MacRae, M. (2007). Bias and variability in purchase intention scales. Journal of the Academy of Marketing Science, 35(4), 617-624. doi:10.1007/s11747-007-0049-x

Wu, W. Y., Lu, H. Y., Wu, Y. Y., \& Fu, C. S. (2012). The effects of product scarcity and consumers' need for uniqueness on purchase intention. International Journal of Consumer Studies, 36(3), 263-274. doi:10.1111/ j.1470-6431.2011.01000.x

Yu, J., \& Yang, J. (2020). Consumer characteristics as predictors of purchase intentions and willingness to pay a premium for men's mass-customized apparel. Journal of Global Fashion Marketing, 11(2), 154-170. doi:10 $.1080 / 20932685.2020 .1728702$ 


\section{ENDNOTES}

This article is extracted from Dr. Ozer-Canarslan's doctoral dissertation supervised by Prof. Barış. If it is possible I would like to point out this information.

Nur Ozer-Canarslan works as an Assistant Professor at the Anadolu University, Open Education Faculty, Marketing Department. She holds MSc and PhD in Marketing. She teaches formal and distance courses on marketing. Her research interest includes Electronic Marketing, Online Consumer Experience, Consumer Behavior, and Customer relationship Management. She has published several articles and book chapters and presented several research papers at various international conferences.

Gülfidan Barış works as a full-time Professor of Marketing at Anadolu University, The Faculty of Economics and Business Administrations. Her research interests are consumer behaviour, consumer happiness and complaint behaviour and brand management. She has books published on both consumer behaviour and complaint management. She has published articles on brand management and marketing strategy. 